\title{
On the relationship between regional trade agreements and agricultural technology and productivity
}

Pascal L Ghazalian

\author{
Correspondence: pascal.ghazalian@ \\ uleth.ca \\ Department of Economics, \\ University of Lethbridge, 4401 \\ University Drive, Lethbridge, Alberta \\ T1K 3M4, Canada
}

\begin{abstract}
The implementation of a Regional Trade Agreement (RTA) is normally accompanied with a rise in market competition levels, in domestic agricultural markets through increases in imports and in foreign agricultural markets through increases in exports. These effects are expected to induce adjustments in agricultural technology and productivity in the importing and exporting countries. This paper analyzes the implications of these adjustments in the context of Viner's (The Customs Union Issue. Carnegie Endowment for International Peace: New York, NY, 1950) conventional partial equilibrium framework with perfectly elastic foreign supply schedules faced by the importing member country. It also examines these implications in the context of Pomfret's (Review of World Economics, 122(3): 439-465, 1986) extended partial equilibrium framework depicting upward-sloping foreign supply schedules for the importing member country. The analysis underscores important changes and redistributions through the RTA's initial benefits and losses, following the RTA-induced adjustments in agricultural technology and productivity. Some analytical considerations are also discussed in the context of vertical agricultural markets. Finally, an empirical investigation is carried out, revealing different implications of membership in the European Union (EU) and its predecessor, the European Economic Community (EEC), for productivity in the agricultural sector.
\end{abstract}

\section{Background}

Regional Trade Agreements (RTAs) represent a prominent feature of the current international trading system. For instance, the number of RTAs that have been reported to the World Trade Organization (WTO) exceeded 500 in 2012 (WTO, 2012). RTAs normally encompass reductions (or eliminations) of policy trade barriers (e.g., tariffs, nontariff barriers) between member countries. Also, RTAs often bring about higher levels of business cooperation and trade facilitation measures (e.g., development of regional trade-enhancing infrastructure) between member countries that further promote intraregional trade flows. RTAs are commonly associated with increases in intra-regional trade flows in agricultural products ${ }^{\mathrm{a}}$. Naturally, such increases in intra-regional trade would be accompanied with a rise in market competition levels, in domestic agricultural markets for producers in importing member countries and in foreign regional agricultural markets for producers in exporting member countries.

(c) 2013 Ghazalian; licensee Springer. This is an Open Access article distributed under the terms of the Creative Commons Attribution License (http://creativecommons.org/licenses/by/2.0), which permits unrestricted use, distribution, and reproduction in any medium, provided the original work is properly cited. 
The formation of an RTA is expected to generate various implications for agricultural technology and productivity in the importing and exporting member countries. This is because the formation of an RTA, which promotes intra-regional increases in agricultural trade flows, would eventually magnify market competition levels. In this context, several studies (e.g., Krugman, 1991; Frankel, 1997; Perdikis, 2007) noted that reductions in regional and bilateral trade barriers would not only decrease market prices, but would also compel firms in RTAs' member countries to upgrade their production technologies and to realize more efficient uses of inputs.

The RTA-induced intensification of market competition, realized through increases in import levels, could potentially provoke domestic firms in the agricultural sector to respond by upgrading their production technology and productivity levels to maintain or expand their domestic market shares vis-à-vis foreign regional exporting competitors. These potential responses are in accordance with many conventional studies indicating that increases in import competition levels would potentially induce domestic firms to upgrade their innovation activities (e.g., Pugel, 1978; Caves, 1985; Levinsohn, 1991). Furthermore, following the formation of a regional trading bloc, domestic firms in the agricultural sector become more exposed to foreign production technologies and practices. In this context, Josling (2011) noted that the formation of RTAs would promote flows of knowledge and technology between member countries, particularly from highly competitive agricultural sectors in some member countries to agricultural sectors in other member countries. This exposure to foreign knowledge and technology could generate supplementary incentives for domestic firms in the agricultural sector to invest in upgrading their production technologies and practices and realize the spillover effects.

Alternatively, the formation of an RTA could lessen the incentives of domestic firms in the agricultural sector of importing member countries to implement technology and productivity upgrading policies. These implications could arguably occur since RTAinduced increases in imports would raise the market competition levels and, consequently, would lead to reductions in the price-to-cost margins. This situation could reduce the market share of domestic firms and the expected returns from technology and productivity upgrading investments, and from innovation activities in general (Aghion and Howitt, 1998; Funk, 2003; Ghazalian, 2012).

RTA-induced increases in exporting activities would expose exporting firms in the agricultural sector of member countries to a more intense market competition in foreign regional agricultural markets, but also to new production technologies and practices. These exposures could potentially stimulate these exporting firms to upgrade their production technologies and productivity levels to further enhance their competitiveness in foreign regional markets and to realize the spillover effects. This argument is consistent with the seminal study on endogenous growth theory of Grossman and Helpman (1991) which identifies the positive effects of increases in exporting activities on innovation activities. Finally, the formation of a regional trading bloc generates larger effective agricultural markets for the exporting agricultural sectors of member countries. These larger agricultural markets could improve the feasibility of investments to upgrade agricultural technology and productivity. Lileeva and Trefler (2010) initially identified equivalent potential effects where larger effective regional markets would enhance the feasibility of investments in innovation activities. 
The analytical literature has paid little attention to adjustments in agricultural technology and productivity, which are typically associated with shifts in supply curves, when examining the effects of RTAs on agricultural trade and welfare through the conventional frameworks. This paper contributes to the literature by analyzing the implications of RTA-induced adjustments in agricultural technology and productivity for the effects of RTAs on agricultural trade and welfare. It investigates the relationship between RTAs and agricultural technology and productivity in the context of Viner's (1950) conventional partial equilibrium framework with perfectly elastic foreign supply schedules faced by the importing member country. It also examines this relationship in the context of Pomfret's (1986) extended partial equilibrium framework depicting upwardsloping foreign supply schedules for the importing member country.

This paper shows changes in the initial benefits and losses from RTAs and depicts their redistributions following the RTA-induced adjustments in agricultural technology and productivity in the importing and exporting member countries. It is important to underscore the relevant study by Anania and McCalla (1995) that examined the implications of some domestic and trade policies, which are commonly used in developing countries, for the distribution of benefits from agricultural technology improvements. Using a partial equilibrium framework, Anania and McCalla (1995) identified different cases where policy interventions increase, reduce, or do not impact the overall benefits from agricultural technology improvements. Yet, in all cases, the distribution of benefits from agricultural technology improvements is found to be different with policy interventions.

\section{A brief review of relevant literature}

Many studies examined the feedback effects from international trade to productivity levels and innovation activities of firms and industries (e.g., Funk, 2003; Salomon and Shaver, 2005; Bloom et al., 2011; Ghazalian, 2012) $)^{\mathrm{b}}$. Other studies focused on investigating the implications of improvements in regional and international market access for the productivity, technology, and innovation activities of firms and industries (e.g., Pavcnik, 2002; Baldwin and Gu, 2004; Costantini and Melitz, 2008; Ederington and McCalman, 2008; Lileeva and Trefler, 2010; Bustos, 2011).

Pavcnik (2002) examined the effects of trade liberalization, expressed through reductions in import policy barriers, on the productivity levels of domestic manufacturing plants in Chile. Pavcnik (2002) underscored rising trends in plant productivity levels in response to increases in market competition that is caused by the surge in import levels. These responses were found to be particularly prominent in the case of import-competing manufacturing sectors. Baldwin and $\mathrm{Gu}$ (2004) analyzed the responses of Canadian manufacturing plants to the continuous reductions in trade barriers between Canada and the rest of the world over time. They found that the continuous reductions in trade barriers have stimulated more Canadian manufacturing plants to participate in exporting activities. They also detected positive feedback effects from increases in exporting activities to productivity levels of individual plants ${ }^{c}$.

Costantini and Melitz (2008) developed a dynamic model that explains the adjustments of firms to trade liberalization. Their model reveals that the anticipation of trade liberalization and the gradual implementation of trade liberalization schemes would provoke firms to innovate. Also, Ederington and McCalman (2008) used a dynamic model to show that international trade positively impacts firms' productivity levels and that the 
implementation of trade liberalization schemes would accelerate the rate of adoption (and diffusion) of new technology.

Lileeva and Trefler (2010) analyzed the implications of the Canada-United States Free Trade Agreement (CUSFTA) for the innovation activities and productivity levels of Canadian manufacturing plants. Specifically, they examined how Canadian manufacturing plants responded to reductions in United States' tariff rates. Lileeva and Trefler (2010) reported that Canadian manufacturing plants with lower productivity levels, which responded to the CUSFTA by starting to export or by exporting more, have realized important productivity gains. These plants have also experienced an increase in their domestic sales. Lileeva and Trefler (2010) showed that these plants have accelerated their adoption rates of new technologies and have increased their innovation rates of new products. Another recent study by Bustos (2011) examined the implications of the formation of the Mercado Común del Sur (MERCOSUR) or the Common Market of the South for the technological upgrading patterns of manufacturing firms in Argentina. The empirical results reveal that manufacturing firms in Argentina that benefited from relatively larger tariff reductions on their exports to Brazil have promoted their investments in upgrading production technology.

\section{Methods}

The seminal partial equilibrium framework of Viner (1950) indentifies the principal implications of RTAs through the trade creation and the trade diversion effects. The trade creation effect implies that the removal (or reduction) of policy trade barriers (e.g., tariffs) between RTA member countries leads to an increase in international trade flows between them, displacing less efficient domestic production. This effect generates positive welfare implications for the importing RTA member country. The trade diversion effect implies that the regional trade preferences induce a diversion of trade from the more efficient RTA non-member country to the less efficient RTA member country. This effect results in negative welfare implications for the importing RTA member country.

The benchmark analytical framework of Viner (1950) is illustrated through Figure 1. Consider one country " $\mathrm{H}$ " and two potential trade partners, country " $\mathrm{F}$ " and country "J". Country $\mathrm{H}$ is assumed to be small in economic sense, being unable to influence the international prices of the product under consideration. Hence, country $\mathrm{H}$ is assumed to be facing perfectly elastic supply schedules of foreign exporters. Let $D_{H}$ and $S_{H}$ represent the demand schedule and supply schedule of country $\mathrm{H}$, respectively. Also, let $\mathrm{S}_{\mathrm{F}}$ and $S_{\mathrm{J}}$ represent the perfectly elastic supply schedules of country $\mathrm{F}$ and country $\mathrm{J}$, respectively ${ }^{d}$. Country $J$ is assumed to be more efficient than country $F$ with $S_{\text {J }}$ placed below $\mathrm{S}_{\mathrm{F}}$. Initially, country $\mathrm{H}$ imposes a non-discriminatory tariff rate, denoted by $\tau$, on imports coming from country $\mathrm{F}$ and from country J. Hence, the tariff-inclusive market prices of imported goods from country $F$ and from country $J$ are represented through $\mathrm{P}_{1} \equiv \mathrm{S}_{\mathrm{F}}(\tau)$ and $\mathrm{P}_{2} \equiv \mathrm{S}_{\mathrm{J}}(\tau)$, respectively. In this initial setup, country $\mathrm{H}$ ends up producing the quantity $\left[\mathrm{OQ}_{1}\right]$ and importing the quantity $\left[\mathrm{Q}_{1} \mathrm{Q}_{2}\right]$ from country J. Country $\mathrm{H}$ does not import any quantity from country $\mathrm{F}$.

The formation of an RTA that includes country $\mathrm{H}$ and country $\mathrm{F}$ as member countries dictates the removal of country H's tariff barriers on imports coming from country F, but keeps them imposed on those coming from country J. These preferences create trade flows from country $\mathrm{F}$ to country $\mathrm{H}$, displacing less efficient country H's domestic 


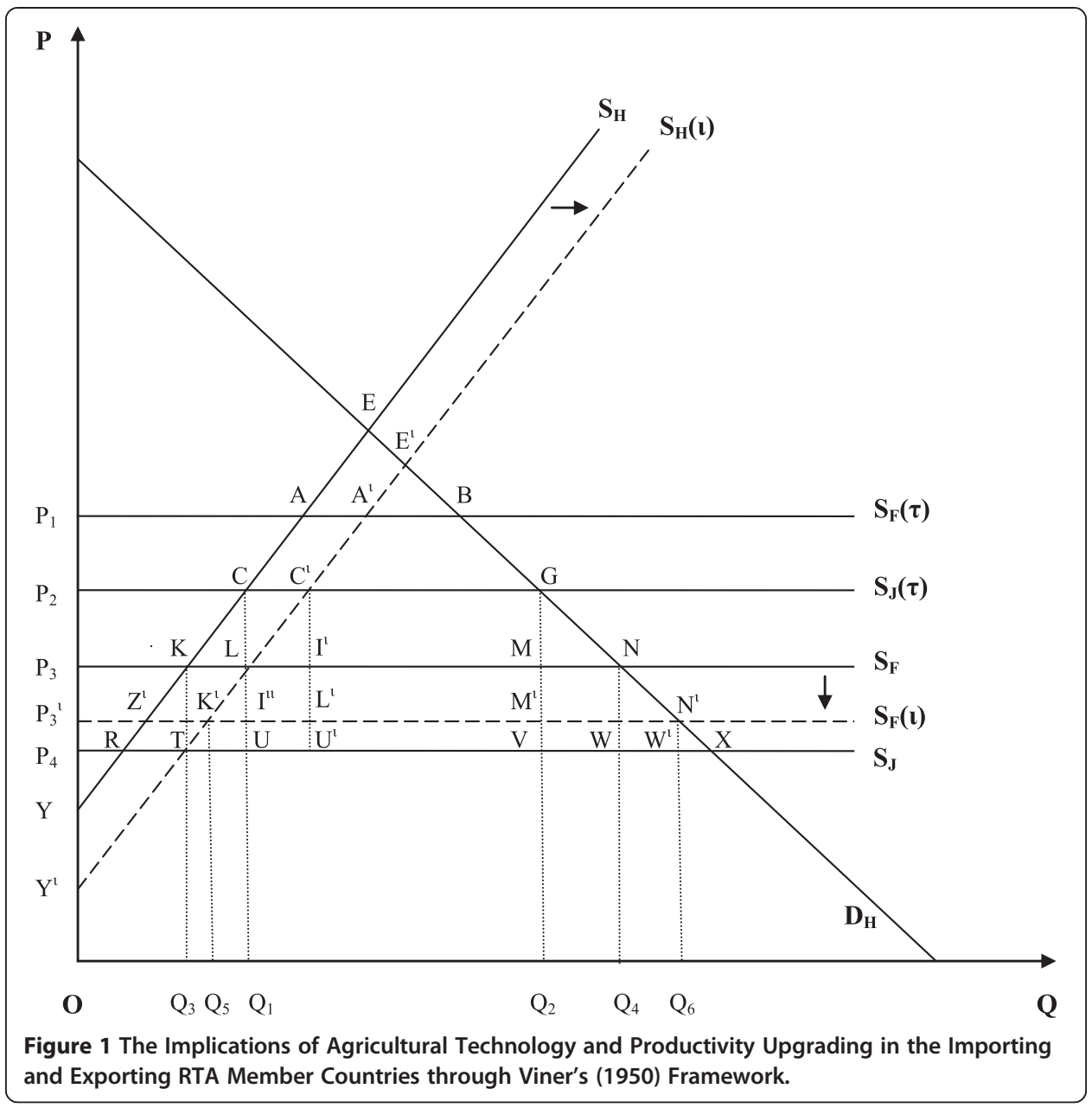

production. However, it diverts trade from the more efficient country $J$ to the less efficient country F. This is because the market price of imported goods from country F, which is now equivalent to $\mathrm{P}_{3} \equiv \mathrm{S}_{\mathrm{F}}$, is lower than the market price of imported goods from country J, which remains at $\mathrm{P}_{2} \equiv \mathrm{S}_{\mathrm{J}}(\tau)$. Consequently, country $\mathrm{H}$ now produces the quantity $\left[\mathrm{OQ}_{3}\right]$ and imports the quantity $\left[\mathrm{Q}_{3} \mathrm{Q}_{4}\right]$ from the RTA member country $\mathrm{F}$. The welfare analysis reveals that the RTA formation induces an increase in consumer surplus by the area $\left[\mathrm{P}_{2} \mathrm{GNP}_{3}\right]$. However, there is a decrease in producer surplus by the area $\left[\mathrm{P}_{2} \mathrm{CKP}_{3}\right]$. Also, tariff revenues, which were initially collected by country H's government from imports coming from country J (i.e., the quantity $\left[\mathrm{Q}_{1} \mathrm{Q}_{2}\right]$ ), are now lost. The loss in governmental tariff revenues is equivalent to the area [CGVU]. Summing up, the net effect on national welfare of country $\mathrm{H}$ from the RTA formation is equivalent to the area [(CKL + GMN)-LMVU] .

Next, following Pomfret (1986), we modify Viner's (1950) basic partial equilibrium framework to allow for upward-sloping supply schedules for both countries J and F. This is illustrated through Figure 2. In this case, both countries J and F could potentially end up exporting to country $\mathrm{H}$, following the RTA formation. Let $\mathrm{IMPD}_{\mathrm{H}}$ represent the import demand schedule of country $\mathrm{H}$, which is equal to the demand schedule minus the supply schedule of country $\mathrm{H}$. Prior to the RTA formation, country $\mathrm{H}$ imports the quantity $\left[\mathrm{OQ}_{1}\right]$ from country $J$ and the quantity $\left[\mathrm{Q}_{1} \mathrm{Q}_{2}\right]$ from country $\mathrm{F}$. The RTA formation induces a decrease in country H's imports from the non-member country $\mathrm{J}$ to $\left[\mathrm{OQ}_{3}\right]$ and 


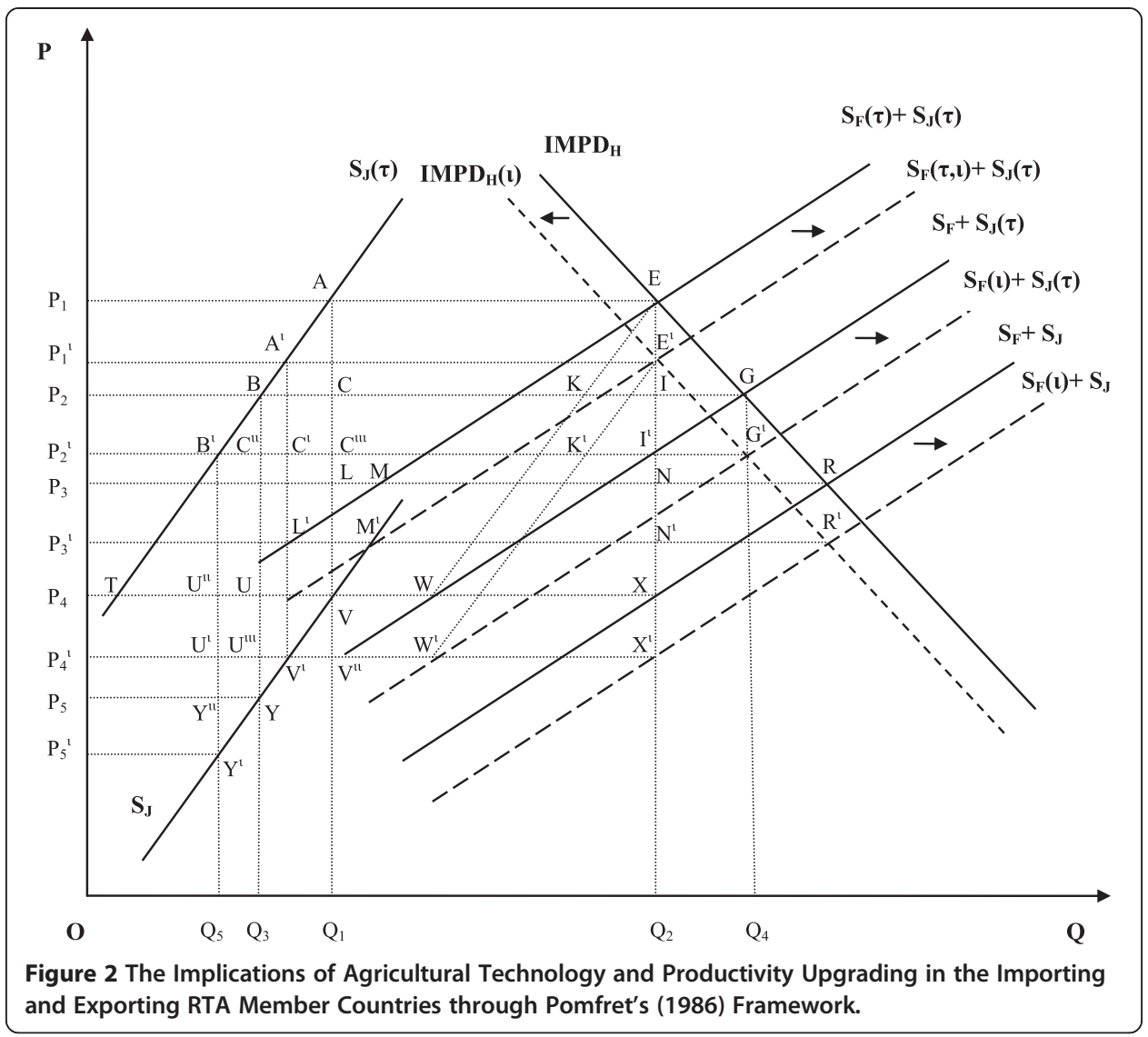

an increase in country H's imports from the member country $F$ to $\left[\mathrm{Q}_{3} \mathrm{Q}_{4}\right]$. Thus, the net welfare effect for the importing country $\mathrm{H}$ from the RTA formation is equivalent to the area $\left[(\mathrm{ABC}+\mathrm{EIG})-\mathrm{BIXU}+\mathrm{P}_{4} \mathrm{UYP}_{5}\right]$, where $[\mathrm{BIXU}]$ depicts the losses from a higher expenditure on the quantity $\left[\mathrm{Q}_{3} \mathrm{Q}_{2}\right]$ that is imported from the RTA member country $F$ whereas $\left[\mathrm{P}_{4} \mathrm{UYP}_{5}\right]$ represents the gains from a lower expenditure on the quantity $\left[\mathrm{OQ}_{3}\right]$ that remains imported from country J. Country F reaps benefits through an increase in welfare. These benefits are represented through the area [CIXV], which depicts the gains from the post-RTA higher price received on the exported quantity $\left[\mathrm{Q}_{1} \mathrm{Q}_{2}\right]$, and through the area [KGW], which depicts the increases in country F's producer surplus. Meanwhile, country J loses from the RTA formation. These losses are represented through the area $\left[\mathrm{P}_{4} \mathrm{UYP}_{5}\right]$, which depicts the effect of the post-RTA lower price received on the exported quantity $\left[\mathrm{OQ}_{3}\right]$, and through the area [UVY], which represents the remaining decreases in country J's producer surplus. Summing up, the net effect of the RTA formation on the global welfare is equivalent to the area [( $\mathrm{ABC}+\mathrm{EIG}+\mathrm{KGW})-\mathrm{BCVY}]$.

\section{Results and Discussion}

The case of technology and productivity upgrading in the exporting and importing RTA member countries

RTAs are commonly associated with increases in intra-regional trade flows, causing a rise in market competition levels in domestic markets for importing countries and in 
foreign markets for exporting countries. As discussed earlier, the RTA-induced intensification of market competition in the importing country could potentially stimulate domestic agricultural producers to invest more in cost-reducing production technologies and to upgrade their productivity levels. Furthermore, domestic agricultural producers in the importing country could incorporate the RTA-induced flow of knowledge into their production routines and, hence, could realize the spillover effects from exposure to foreign technology and production practices. This scenario can be related to the studies of Pugel (1978), Caves (1985), and Pavcnik (2002), among others. Exporting agricultural producers, which encounter higher levels of market competition in regional markets following the RTA formation, are also compelled to upgrade their agricultural technology and productivity levels. They can similarly incorporate the knowledge spillover and learning-by-exporting effects into their production practices. This scenario can be related to the studies of Baldwin and Gu (2004), Lileeva and Trefler (2010), and Bustos (2011), among others.

The implications of these RTA-induced upgrading of agricultural technology and productivity levels are illustrated through Figure 1 using Viner's (1950) framework and through Figure 2 using Pomfret's (1986) framework. For country H, these upgrading adjustments are graphically depicted through a rightward parallel shift from $S_{H}$ to $S_{H}(t)$ in Figure 1 and through a leftward parallel shift from $\operatorname{IMPD}_{\mathrm{H}}$ to $\operatorname{IMPD}_{\mathrm{H}}(\mathrm{l})$ in Figure 2. For country $\mathrm{F}$, they are graphically expressed through a downward parallel shift and a rightward parallel shift from $S_{F}$ to $S_{F}(\mathrm{l})$, as depicted in Figure 1 and Figure 2, respectively.

Figure 1 shows that country H's imports would increase from the pre-RTA quantity $\left[\mathrm{Q}_{1} \mathrm{Q}_{2}\right]$ to the post-RTA pre-adjustments quantity $\left[\mathrm{Q}_{3} \mathrm{Q}_{4}\right]$, which eventually increases further to the post-RTA post-adjustments quantity $\left[\mathrm{Q}_{5} \mathrm{Q}_{6}\right]^{\mathrm{f}}$. Prior to the occurrence of any adjustment, the RTA formation induces an initial increase in the consumer surplus in country $\mathrm{H}$ by the area $\left[\mathrm{P}_{2} \mathrm{GNP}_{3}\right]$. Then, the RTA-induced downward shift from $\mathrm{S}_{\mathrm{F}}$ to $\mathrm{S}_{\mathrm{F}}(\mathrm{l})$ would further augment the consumer surplus in country $\mathrm{H}$ by the additional area $\left[\mathrm{P}_{3} \mathrm{NN}^{\prime} \mathrm{P}_{3}^{1}\right]$. Also, prior to the occurrence of any adjustment, the RTA formation results in an initial decrease in the surplus of domestic agricultural producers in country $\mathrm{H}$ by the area $\left[\mathrm{P}_{2} \mathrm{CKP}_{3}\right]$. The occurrence of agricultural technology and productivity upgrading adjustments in country $\mathrm{H}$ would generate an increase in producer surplus by the area [KLY'Y]. Meanwhile, the occurrence of agricultural technology and productivity upgrading adjustments in country $\mathrm{F}$ would result in a decrease in producer surplus by the area $\left[\mathrm{P}_{3} \mathrm{LK}^{1} \mathrm{P}_{3}^{\mathrm{l}}\right]$. Hence, following these adjustments, the net effect of the RTA formation on country H's producer surplus becomes equivalent to the area $\left[Z^{\prime} K^{\prime} Y^{\prime} Y-\right.$ $\left.\mathrm{P}_{2} \mathrm{CZ}^{\mathrm{l}} \mathrm{P}_{3}^{\mathrm{t}}\right]$. Accordingly, there is a higher likelihood of net gains in country H's producer surplus when the magnitude of the rightward shift from $S_{H}$ to $S_{H}(l)$ is relatively larger than the magnitude of the downward shift from $S_{F}$ to $S_{F}(l)$. Lastly, prior to the occurrence of these adjustments, the initial losses in governmental tariff revenues are equivalent to the basic area [CGVU]. Following the occurrence of these adjustments, the current implicit losses in governmental tariff revenues become equivalent to the smaller area $\left[\mathrm{C}^{\prime} \mathrm{GVU}^{\prime}\right]^{\mathrm{g}}$.

Thus, following the occurrence of these agricultural technology and productivity upgrading adjustments, the net welfare effect of the RTA formation for country $\mathrm{H}$ becomes equivalent to the area $\left[C^{\prime} K^{\prime} L^{\prime}+G M^{\prime} N^{\prime}+C C^{\prime} Y^{\prime} Y-L^{\prime} M^{\prime} V U^{\prime}\right]$. This net welfare effect can be readily compared to the initial net welfare effect (i.e., prior to the 
occurrence of these upgrading responses), which is equivalent to the area [CLK + GMN-LMVU]. Hence, these upgrading adjustments would raise the initial positive welfare effect of the RTA formation, expressed through the trade creation effect, by the supplementary area $\left[\mathrm{LI}^{\prime} \mathrm{L}^{\prime} \mathrm{K}^{\prime}+\mathrm{MNN}^{\prime} \mathrm{M}^{1}+\mathrm{CC}^{1} \mathrm{Y}^{\prime} \mathrm{Y}\right]$. Concurrently, they would reduce the initial negative welfare effect of the RTA formation, expressed through the trade diversion effect, by the area $\left[\mathrm{LI}^{\prime} \mathrm{U}^{\prime} U+\mathrm{I}^{\prime} M M^{\prime} L^{\prime}\right]$. Consequently, these upgrading adjustments would increase the probability to realize higher net positive welfare effects from the RTA formation ${ }^{\mathrm{h}}$.

Figure 2 presents the implications of the RTA-induced upgrading of agricultural technology and productivity levels using Pomfret's (1986) framework. For ease of exposition, Figure 2 illustrates the case where the shift margins between the parallel schedules $S_{\mathrm{F}}(\tau)+S_{\mathrm{J}}(\tau), S_{\mathrm{F}}+S_{\mathrm{J}}(\tau)$, and $S_{\mathrm{F}}+S_{\mathrm{J}}$ are equivalent to those between the parallel schedules $S_{F}(\tau, l)+S_{J}(\tau), S_{F}(l)+S_{J}(\tau)$, and $S_{F}(l)+S_{J}$. Also, following the RTA formation, Figure 2 illustrates the case where the pre-upgrading total imported quantity by country $\mathrm{H}$ is equivalent to the post-upgrading total imported quantity, remaining unchanged at $\left[\mathrm{OQ}_{4}\right]$. Accordingly, following the RTA formation, the occurrence of agricultural technology and productivity upgrading adjustments causes increases in country F's exports to country $\mathrm{H}$ from the quantity $\left[\mathrm{Q}_{3} \mathrm{Q}_{4}\right]$ to the quantity $\left[\mathrm{Q}_{5} \mathrm{Q}_{4}\right]$ and decreases in country J's exports to country $\mathrm{H}$ from the quantity $\left[\mathrm{OQ}_{3}\right]$ to the quantity $\left[\mathrm{OQ}_{5}\right]$.

Following the occurrence of these upgrading adjustments, the net welfare effect for the importing country $\mathrm{H}$ changes from the area [(ABC + EIG)-BIXU $\left.+\mathrm{P}_{4} \mathrm{UYP}_{5}\right]$ (see previous section) to the area $\left[\left(A^{\prime} B^{\prime} C^{l}+E^{\prime} I^{\prime} G^{\prime}\right)-B^{\prime} I^{\prime} X^{\prime} U^{\prime}+P_{4}^{\prime} U^{\prime} Y^{\prime} P_{5}^{\prime}\right]$. Hence, the postupgrading adjustments resulted in larger negative area that is augmented by $\left[\mathrm{B}^{\prime} \mathrm{C}^{\mathrm{II}} \mathrm{U}^{\mathrm{II}} \mathrm{U}^{\prime}\right]$, reflecting a higher expenditure on the additional imports from country $\mathrm{F}$. Also, the positive area is reduced by [ $\left.\mathrm{U}^{\mathrm{\prime \prime}} U \mathrm{Y}^{\mathrm{u}}\right]$. The latter reflects the implications of the post-upgrading adjustments, leading to a smaller imported quantity from country J. In other words, following the RTA formation, the benefits from a lower expenditure on imports from country $J$ at the post-upgrading adjustments equilibrium are smaller than those at the pre-upgrading adjustments equilibrium. Summing up, the occurrence of agricultural technology and productivity upgrading adjustments has resulted in a decrease in the benchmark net welfare effect of RTA formation for the importing country $\mathrm{H}$.

Turning to the RTA exporting member country F, the post-upgrading gains from the RTA formation, which are equivalent to the area $\left[C^{1} I^{1} X^{1} V^{t}+K^{1} G^{1} W^{1}\right]$, are higher than the pre-upgrading gains, which are equivalent to the area [CIXV $+\mathrm{KGW}$ (see previous section). Specifically, the net post-upgrading increases in country F's welfare, resulting from a higher price received on additional exports, is equivalent to the area $\left[C^{\prime} C^{\mathrm{II}} \mathrm{V}^{\mathrm{ll}} \mathrm{V}^{\mathrm{t}}\right]$. Meanwhile, the pre-upgrading gains and the post-upgrading gains in country F's producer surplus (i.e., the areas $[\mathrm{KGW}]$ and $\left[\mathrm{K}^{\prime} \mathrm{G}^{\prime} \mathrm{W}^{\prime}\right]$, respectively) are equivalent by construction under the current scenario. Turning to the non-RTA member country J, the losses from the RTA formation are attenuated, being reduced from the pre-upgrading adjustments area $\left[\mathrm{P}_{4} \mathrm{UYP}_{5}+\mathrm{UVY}\right]$ (see previous section) to the post-upgrading adjustments area $\left[\mathrm{P}_{4}^{1} \mathrm{U}^{\prime} \mathrm{Y}^{\prime} \mathrm{P}_{5}^{\mathrm{l}}+\mathrm{U}^{\prime} \mathrm{V}^{\prime} \mathrm{Y}^{\prime}\right]$. Hence, given that [UVY] is equivalent to $\left[\mathrm{U}^{\prime} V^{\prime} Y^{\prime}\right]$ by construction, the post-upgrading losses are lower than the pre-upgrading losses by the area $\left[\mathrm{U}^{\mathrm{\prime l}} U \mathrm{YY}^{\mathrm{u}}\right]$. The latter is derived from the lower quantities subjected to an RTA-induced lower price. 
Finally, the pre-upgrading and the post-upgrading changes in global welfare remain equivalent through the scenario presented in Figure 2. In other words, we get:

$$
\left[\Omega^{\imath}(\text { with RTA })-\Omega^{\imath}(\text { without RTA })\right]=[\Omega(\text { with RTA })-\Omega(\text { without RTA })]
$$

where $\Omega^{\prime}$ and $\Omega$ depict the global welfare with and without agricultural technology and productivity upgrading adjustments, respectively. Rearranging, Equation (1) can be expressed as:

$$
\left[\Omega^{\iota}(\text { with RTA })-\Omega(\text { with RTA })\right]=\left[\Omega^{\iota}(\text { without RTA })-\Omega(\text { without RTA })\right]
$$

Equation (2) implies that the changes in global welfare resulting from agricultural technology and productivity upgrading following the formation of RTA are equivalent to those that would result from a comparable upgrading that occurs in the absence of RTA. These results are reminiscent of those discussed in Anania and McCalla (1995), indicating that the global welfare gains from the adoption of new technology in the presence of distorting policies (e.g., export tax) are equivalent to the global welfare gains from the adoption of new technology under free trade.

\section{The case of technology and productivity upgrading in the exporting RTA member country and downgrading in the importing RTA member country}

Through this alternative scenario, the RTA formation induces the agricultural sector of the exporting member country F to upgrade its technology and productivity. However, the RTA formation forces the domestic agricultural sector in the importing member country $\mathrm{H}$ to reduce its budget allocated for technology and productivity upgrading and maintenance. Such reductions would eventually lead to decreases in productivity and efficiency levels. This scenario can be related to the studies of Aghion and Howitt (1998), Funk (2003), and Ghazalian (2012), among others. Figure 3 illustrates these adjustments through Viner's (1950) framework, where the supply curve of country F exhibits a downward parallel shift from $S_{\mathrm{F}}$ to $S_{\mathrm{F}}(\mathrm{l})$ and where the supply curve of country $\mathrm{H}$ experiences a leftward parallel shift from $S_{H}$ to $S_{H}(\mathfrak{l})$. Hence, Figure 3 indicates that country H's imports would rise from the pre-RTA quantity $\left[\mathrm{Q}_{1} \mathrm{Q}_{2}\right]$ to the post-RTA pre-adjustments quantity $\left[\mathrm{Q}_{3} \mathrm{Q}_{4}\right]$, and further to the post-RTA postadjustments quantity $\left[\mathrm{Q}_{5} \mathrm{Q}_{6}\right]$.

Figure 3 shows that the RTA formation would initially increase the consumer surplus by the area $\left[\mathrm{P}_{2} \mathrm{GNP}_{3}\right]$. This area is further increased by $\left[\mathrm{P}_{3} \mathrm{NN}^{\prime} \mathrm{P}_{3}^{\prime}\right]$ due to country F's agricultural technology and productivity upgrading responses. The producer surplus would initially decrease by the area $\left[\mathrm{P}_{2} \mathrm{CKP}_{3}\right]$ due to the increase in import competition levels brought about by the RTA formation. The producer surplus would experience a further reduction by the area $\left[\mathrm{P}_{3} \mathrm{KZ}^{1} \mathrm{P}_{3}^{1}\right]$ due the RTA-induced downward shift of country F's supply curve and by the area $\left[\mathrm{K}^{\prime} \mathrm{Z}^{\prime} \mathrm{YY}^{\prime}\right]$ due to the RTA-induced leftward shift of country H's supply curve. Also, following the RTA formation, the pre-adjustments losses in governmental tariff revenues are equivalent to the area [CGVU]. Comparatively, the post-adjustments losses in governmental tariff revenues become larger and are equivalent to the area $\left[\mathrm{C}^{\prime} G V \mathrm{U}^{\prime}\right]^{\mathrm{i}}$.

Summing up, the post-adjustments net change in national welfare of country $\mathrm{H}$ is equivalent to the area $\left[K Z^{\prime} L^{\prime}+G M^{\prime} N^{\prime}-C^{\prime} C K-L^{\prime} M^{\prime} V U^{\prime}-K^{\prime} Z^{\prime} Y Y^{\prime}\right]$. This outcome can be compared to the pre-adjustments net change in national welfare of country $\mathrm{H}$, which is 


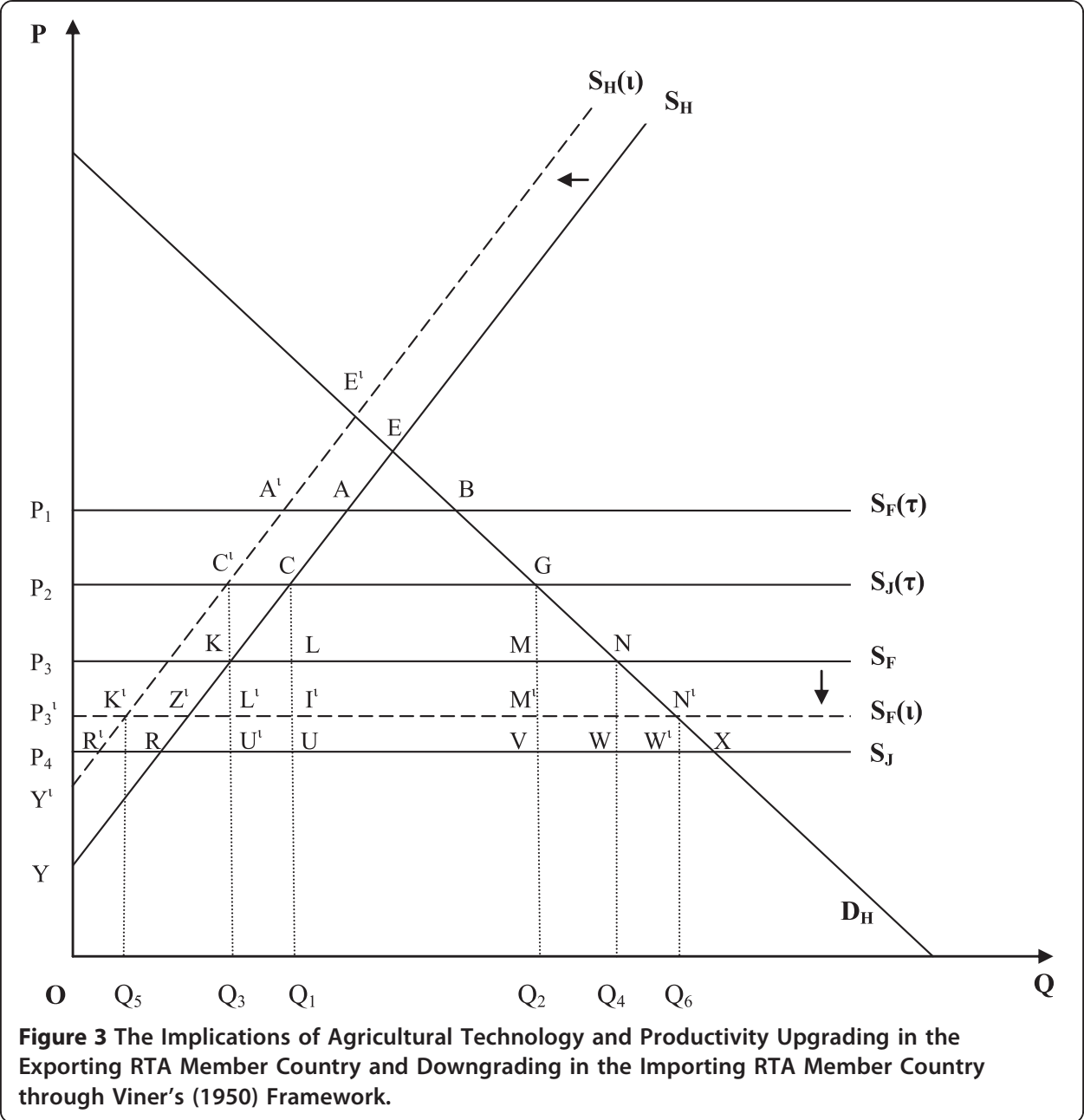

equivalent to the area [CKL + GMN-LMVU]. Accordingly, the adjustments in agricultural technology and productivity would result in an ambiguous change in the RTA's positive welfare effects, which are augmented by the area $\left[K Z^{\prime} L^{\prime}+M N N^{\prime} M^{\prime}\right]$ and reduced by the area [CKL]. The likelihood of a post-adjustments increase in the RTA's positive welfare effects can occur with a larger downward shift from $S_{F}$ to $S_{F}(t)$. These adjustments would also cause an ambiguous change in the RTA's negative welfare effects, which are magnified by the area $\left[C^{\prime} C K+L^{1} I^{1} U U^{\prime}+K^{\prime} Z^{1} Y Y^{\prime}\right]$, but are lessened by the area $\left[\mathrm{LMM}^{\mathrm{t} I} \mathrm{I}^{\mathrm{j}}\right]^{\mathrm{j}}$. Hence, the larger is the downward shift from $S_{\mathrm{F}}$ to $\mathrm{S}_{\mathrm{F}}(\mathrm{t})$ and the smaller is the leftward shift from $S_{H}$ to $S_{H}(\iota)$, the higher is the likelihood of a post-adjustments reduction in the RTA's negative welfare effects.

Figure 4 illustrates the corresponding scenario through Pomfret's (1986) framework. As in Figure 2, there are parallel rightward shifts in the export supply schedules with equivalent shift margins. Meanwhile, Figure 4 depicts a parallel rightward shift in the import demand curve. Also, following the RTA formation, Figure 4 illustrates the case where the corresponding pre-adjustments and post-adjustments equilibrium prices remain unchanged.

Following the RTA formation, Figure 4 indicates that the net welfare effect for the importing country $\mathrm{H}$ changes from the pre-adjustments area [( $\mathrm{ABC}+\mathrm{EIG})-\mathrm{BIXU}+\mathrm{P}_{4} \mathrm{UYP}_{5}$ ] 


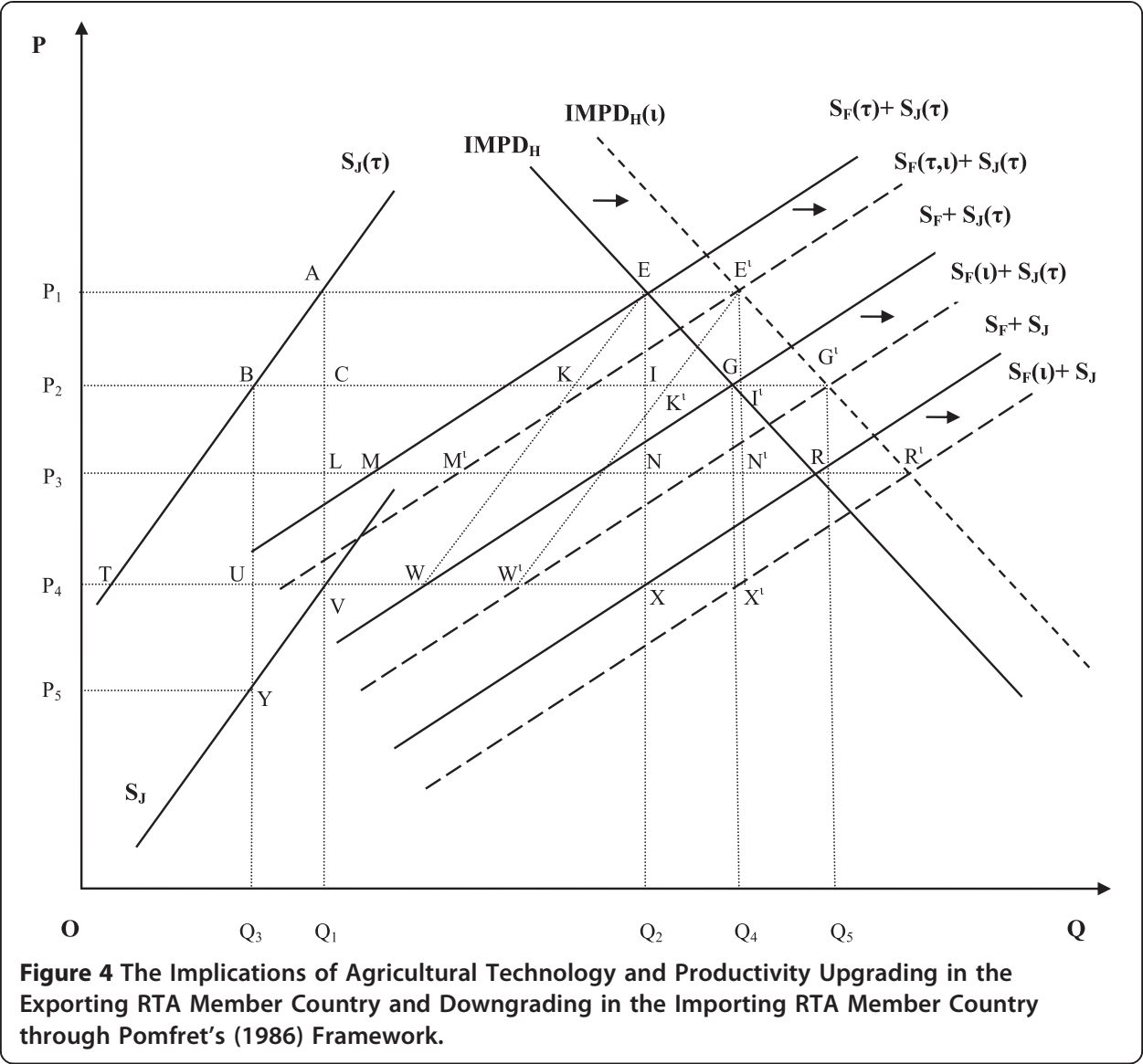

(see previous section) to the post-adjustments area $\left[\left(A B C+E^{\prime} I^{\prime} G^{\prime}\right)-B I^{\prime} X^{\prime} U+P_{4} U Y P_{5}\right]$. Hence, there is a post-adjustments decrease in net welfare by the area $\left[\mathrm{II}^{\prime} \mathrm{X}{ }^{\prime} \mathrm{X}\right]$. These losses are associated with a higher expenditure on the quantity $\left[\mathrm{Q}_{2} \mathrm{Q}_{4}\right]$ that is imported from country F. Meanwhile, following the RTA formation, the gains of country F are increased from the pre-adjustments area [CIXV $+\mathrm{KGW}$ ] (see previous section) to the postadjustments area $\left[\mathrm{CI}^{\prime} \mathrm{X}^{\prime} \mathrm{V}+\mathrm{K}^{\prime} \mathrm{G}^{\prime} \mathrm{W}^{\prime}\right]$. Hence, the post-adjustments increase in country F's gains is equivalent to the area [IGX'X]. Finally, the pre-adjustments and post-adjustments losses of country J from the RTA formation remain unchanged at $\left[\mathrm{P}_{4} \mathrm{UYP}_{5}+\mathrm{UVY}\right]$ (see previous section). This outcome is resulting from the equivalent pre-adjustments and post-adjustments quantities that are imported by country $\mathrm{H}$ from country $\mathrm{J}$ (i.e., $\left[\mathrm{OQ}_{3}\right]$ ) and from the equivalent pre-adjustments and post-adjustments equilibrium prices received by country J producers (i.e., $\mathrm{P}_{5}$ ). The scenario presented in Figure 4 implies that the pre-adjustments and post-adjustments changes in global welfare are equivalent. Hence, the previously discussed Equation (1) and Equation (2) also pertain for this scenario.

\section{Some analytical considerations in the case of vertical agricultural markets}

RTAs commonly encompass preferential market access schemes covering verticallyrelated agricultural products. These regional trade preferences for imports of upstream (primary or intermediate) and downstream (final) products could have various effects on market competition levels. Accordingly, they could induce various interactive implications 
for technology and productivity of upstream and downstream agricultural industries along the supply chain.

Consider the scenario where country $\mathrm{F}$ is an exporter of the downstream product and an importer of the upstream product. Also, assume that the downstream agricultural industry in country F benefits from significant RTA-induced tariff reductions on imports of the upstream product that are purchased from country H. Consequently, the export supply schedule of country F's downstream product to country $\mathrm{H}$ would experience a downward/rightward shift caused by lower prices of the upstream product. This downward/rightward shift would increase exports and, hence, the regional market share of country F's downstream agricultural industry. Then, the previously discussed dynamic patterns could prevail once again where increases in market shares would further stimulate country F's downstream agricultural industry to upgrade its technology and productivity. These adjustments would result in a supplementary downward shift and rightward shift in $\mathrm{S}_{\mathrm{F}}(\mathrm{t})$ through Viner's (1950) framework (i.e., Figure 1 and Figure 3) and Pomfret's (1986) framework (i.e., Figure 2 and Figure 4), respectively.

Now, the RTA-induced growth in the exporting activities of country H's upstream agricultural industry would similarly enhance its technology and productivity. Consequently, this upstream agricultural industry would eventually supply its product at lower prices to the downstream agricultural industries in both RTA member countries $\mathrm{H}$ and $\mathrm{F}$. Then, the downstream agricultural industry in country F would further increase its market share within the regional trading bloc, generating supplementary positive feedback effects on its technology and productivity.

The lower market prices of the upstream product could also enhance the competitiveness of country H's downstream agricultural industry. However, country H's downstream agricultural industry would be simultaneously facing higher import competition levels from country F. This is because, in this scenario, country F's downstream agricultural industry also benefits from the lower prices of the upstream product. For instance, consider the case where the increases in the downstream market competition levels, which are promoted by the lower prices of the upstream product, outweigh the corresponding competitiveness benefits for country H's downstream agricultural industry. Then, the previously discussed patterns could prevail where increases in import competition could either induce country H's downstream agricultural industry to upgrade its technology and productivity (as illustrated in the previous section) or to reduce its technology and productivity upgrading efforts (as illustrated in the previous section). Reversed responses could arguably prevail when the competitiveness benefits for country H's downstream agricultural industry, which are derived from the lower prices of the upstream product, more than compensate the corresponding effects of increases in the downstream market competition levels.

Next, consider an alternative scenario where country $\mathrm{F}$ is an exporter of the upstream and the downstream products. The RTA-induced increases in exports of country F's upstream and downstream agricultural industries would expand their regional market shares. These increases would stimulate technology and productivity upgrading activities in both industries. Thus, the downstream export supply schedule of country $\mathrm{F}$ would experience a basic downward shift in Viner's (1950) framework (i.e., Figure 1 and Figure 3) and a basic rightward shift in Pomfret's (1986) framework (i.e., Figure 2 and Figure 4) associated with the upgrading activities in the downstream industry. Also, 
the downstream export supply schedule of country F would experience a corresponding supplementary shift resulting from the lower prices of the upstream product brought about through the upgrading activities in the upstream industry.

The downstream agricultural industry in country $\mathrm{H}$ would be facing higher levels of import competition, which are derived from the technology and productivity upgrading efforts in country F's downstream and upstream industries. However, it would be simultaneously benefiting from the extra lower prices of the upstream product, which are derived from the upgrading efforts in country F's upstream industry. For instance, consider the case where the effects of the additional increases in import competition levels outweigh the benefits from the extra lower prices of the upstream product. Then, country H's downstream agricultural industry would respond by either upgrading its technology and productivity efforts (as illustrated in the previous section) or by reducing them (as illustrated in the previous section). Reversed responses could occur when the benefits from the extra lower prices of the upstream product outweigh the corresponding effects of increases in import competition levels.

\section{Empirical investigation}

This section presents an empirical investigation on the implications of membership in the European Union (EU) and its predecessor, the European Economic Community $(\mathrm{EEC})$, for productivity in the agricultural sector. The productivity measure is derived from the World Bank Indicators' database, and it is represented through the value added per worker in the agricultural sector (data are presented in constant 2000 US dollars). The value added equals the value of output of the agricultural sector less the value of intermediate inputs. The agricultural sector is defined according to the International Standard Industrial Classification (ISIC), and it corresponds to the divisions 1-5. The dataset used through the empirical investigation covers observations for 14 European countries $^{\mathrm{k}}$ over 29 years (1981-2009).

It is commonly perceived that the accession to the EU/EEC has led to increases in market competition levels faced by agricultural producers in member countries. This is because the EU/EEC has been Europe's (and world's) largest trading bloc and has been characterized by significant depth of economic integration and removal of trade barriers among member countries since formation. As discussed through this study, RTA-induced increases in market competition levels would likely cause adjustments in agricultural productivity. These adjustments are typically associated with shifts in supply curves. As shown through the analytical framework, shifts in supply curves would have implications for trade flows and national welfare. Given the dynamic nature of agricultural productivity patterns, the empirical specification compares productivity growth between EU/EEC member countries and other non-EU/EEC European countries representing the reference group. It is used to examine the occurrence of diverging shifts in supply curves of EU/EEC member countries from those of non-EU/EEC European countries. The estimating empirical model is a basic growth equation (Baumol, 1986; Caselli et al., 1996), and it is given by:

$$
\ln \left(Y_{i t}\right)-\ln \left(Y_{i t-T}\right)=\beta \ln \left(Y_{i t-T}\right)+\mathbf{E U}_{\mathbf{i t}} \boldsymbol{\delta}+\gamma_{t}+\varepsilon_{i t}
$$

where $Y_{i t}$ represents the productivity of country $i$ at time $t, \mathbf{E U}_{\mathbf{i t}}$ is a row-vector of binary variables that take the value of one when the corresponding country $i$ is a member of the EU/EEC at time $t$ and zero otherwise. This vector includes a binary variable for the 
Original Member Countries $(\mathrm{OMCs})^{1}$, binary variables for Denmark and the United Kingdom that accessed the EEC in 1973, binary variables for Portugal and Spain that become members of the EEC in 1986, and binary variables for Austria, Finland, and Sweden that become members of the EU in 1995. The reference group for these binary variables covers the European countries that are not members of the EU/EEC. It comprises countries that are continuing and previous members of the European Free Trade Association (EFTA) in our dataset ${ }^{\mathrm{m}}$. The parameter $\gamma_{t}$ is a time-specific effect, and $\varepsilon_{i t}$ is a stochastic error term. The regressions are implemented with five-year lags (i.e., $T=5$ ).

The empirical results are presented in Table 1. Column (i) shows the estimated coefficients with robust standard errors. The estimated coefficient on the lagged productivity variable (i.e., $\hat{\beta}$ ) is negative and statistically significant at the $1 \%$ level. This finding indicates a convergence in productivity of the European countries in the agricultural sector over time. The implied convergence rate is 0.027 or $2.7 \%$. The estimated coefficients on the EU/EEC binary variables for OMCs and for Denmark are positive and statistically significant at the $1 \%$ level. They indicate higher average productivity growth rates by $10.2 \%$

Table 1 Empirical results

\begin{tabular}{|c|c|c|c|}
\hline & (i) & (ii) & (iii) \\
\hline \multirow[t]{2}{*}{ Lagged Productivity } & $-0.125^{* * *}$ & $-0.130^{* * *}$ & $-0.122^{* * *}$ \\
\hline & $(0.022)$ & $(0.020)$ & $(0.022)$ \\
\hline \multirow[t]{2}{*}{ EU/EEC member (OMCs) } & $0.097^{* * *}$ & $0.094^{* * *}$ & $0.087^{* * *}$ \\
\hline & $(0.016)$ & $(0.017)$ & $(0.022)$ \\
\hline \multirow[t]{2}{*}{ EU/EEC member (Denmark) } & $0.113^{* * *}$ & $0.110^{* * *}$ & $0.103^{* * *}$ \\
\hline & $(0.034)$ & $(0.036)$ & $(0.038)$ \\
\hline \multirow[t]{2}{*}{ EU/EEC member (United Kingdom) } & -0.027 & -0.029 & -0.037 \\
\hline & $(0.019)$ & $(0.019)$ & $(0.025)$ \\
\hline \multirow[t]{2}{*}{ EU/EEC member (Portugal) } & $-0.185^{* * *}$ & $-0.195^{* * *}$ & $-0.190^{* * *}$ \\
\hline & $(0.045)$ & $(0.044)$ & $(0.047)$ \\
\hline \multirow[t]{2}{*}{ EU/EEC member (Spain) } & 0.040 & 0.034 & 0.032 \\
\hline & $(0.032)$ & $(0.032)$ & $(0.034)$ \\
\hline \multirow[t]{2}{*}{ EU/EEC member (Austria) } & -0.023 & -0.029 & -0.033 \\
\hline & $(0.027)$ & $(0.027)$ & $(0.032)$ \\
\hline \multirow[t]{2}{*}{ EU/EEC member (Finland) } & $0.093^{* * *}$ & $0.088^{* * *}$ & $0.082^{* *}$ \\
\hline & $(0.029)$ & $(0.029)$ & $(0.034)$ \\
\hline \multirow[t]{2}{*}{ EU/EEC member (Sweden) } & $0.109^{* * *}$ & $0.106^{* * *}$ & $0.098^{* * *}$ \\
\hline & $(0.025)$ & $(0.024)$ & $(0.032)$ \\
\hline \multirow[t]{2}{*}{ Trend } & & $0.003^{* * *}$ & \\
\hline & & $(0.001)$ & \\
\hline \multirow[t]{2}{*}{ EFTA } & & & -0.014 \\
\hline & & & $(0.029)$ \\
\hline Time-specific effects & Yes & No & Yes \\
\hline Number of observations & 336 & 336 & 336 \\
\hline R-squared & 0.378 & 0.329 & 0.378 \\
\hline
\end{tabular}

Notes: The dependent variable is productivity growth rate $\ln \left(Y_{i t}\right)-\ln \left(Y_{i t-T}\right)$, where $Y_{i t}$ represents the productivity of country $i$ at time $t$. Productivity is measured through the value added per worker (constant 2000 US dollars) in the agricultural sector. Robust standard errors are reported in parenthesis. The symbols "***", "**", and "** denote statistical significance at the $1 \%, 5 \%$, and $10 \%$ levels, respectively. 
for OMCs and by $12.0 \%$ for Denmark compared to the average productivity growth rates of the European countries that are not members of the EU/EEC, ceteris paribus. Also, the estimated coefficients on the EU/EEC binary variables for Finland and Sweden, which joined the EU in 1995 and ceased to be member countries of the EFTA, are positive and statistically significant at the $1 \%$ level. They indicate higher average productivity growth rates by $9.7 \%$ and by $11.5 \%$ compared to the reference group, respectively. These results can be expressed through an RTA-induced shift in the supply curve (relative to the reference supply curve) as depicted through Figure 1 and Figure 2. This is consistent with an analytical scenario where the EU/EEC-induced intensification in market competition has provoked producers in the agricultural sector of OMCs, Denmark, Finland, and Sweden to respond by upgrading their production technology and productivity levels to maintain or expand their market shares vis-à-vis foreign regional competitors.

The estimated coefficient for Portugal's binary variable is found to be negative and statistically significant at the $1 \%$ level. It indicates that Portugal has lower productivity growth rates compared to the reference group by $16.9 \%$, ceteris paribus. This result can be expressed through an RTA-induced shift in the supply curve (relative to the reference supply curve) as depicted through Figure 3 and Figure 4. This is consistent with an analytical scenario where the EU/EEC-induced raise in market competition levels has lessened the incentives of agricultural producers in Portugal to implement technology and productivity upgrading policies. This outcome could occur through decreases in price-to-cost margins, which reduce the market share of producers and the expected returns from technology and productivity upgrading investments. The estimated coefficients on the EU/EEC binary variables for the United Kingdom, Spain, and Austria are not statistically significant. Overall, the results suggest international differences in the implications of EU/EEC membership for productivity in the agricultural sector across the EU/EEC countries.

Column (ii) shows the results when substituting the time-specific effects with a time trend variable. The results remain equivalent to those presented in column (i). The estimated coefficient on the time trend variable is positive and statistically significant at the $1 \%$ level. Finally, we estimate the empirical model when including a binary variable that takes the value of one for the continuing member countries of EFTA (i.e., Iceland, Norway, and Switzerland) and zero otherwise. Hence, the reference group for the EU/ EEC binary variables becomes the previous EFTA member countries (i.e., Austria, Finland, and Sweden) prior to their accession to the EU in 1995. The results, presented in column (iii), are similar to those reported in column (i).

\section{Conclusions}

This paper aims to enhance our understanding of the relationship between RTAs and agricultural technology and productivity. The implementation of an RTA is expected to induce increases in market competition levels, in domestic markets through increases in imports and in foreign markets through increases in exports. These increases in market competition levels could eventually result in important implications for agricultural technology and productivity in importing and exporting member countries of regional trading blocs. This paper examines these implications in the context of Viner's (1950) conventional partial equilibrium framework with perfectly elastic foreign supply schedules faced by the importing member country, and in the context of Pomfret's (1986) extended 
partial equilibrium framework depicting upward-sloping foreign supply schedules for the importing member country.

Different scenarios are implemented and discussed where RTA's initial benefits and losses experience considerable changes following the RTA-induced adjustments in agricultural technology and productivity in the importing and exporting member countries. The analysis underlines important redistributions of the benefits and losses between importing and exporting member countries and between consumers and producers. Also, the implications of these adjustments for global welfare are found not to be necessarily different in the presence or absence of regional trading blocs. This outcome is revealed through the illustrated scenarios which show equivalence of these implications with and without the RTA in place. This paper also presents and discusses some analytical considerations in the case of vertical agricultural markets where RTA preferential schemes cover imports of upstream (primary or intermediate) and downstream (final) products.

Following the analytical scenarios, this paper carries out an empirical investigation on the implications of membership in the EU/EEC for productivity in the agricultural sector. The results from a basic growth equation indicate that many EU/EEC member countries (OMCs, Denmark, Finland, and Sweden) have higher average productivity growth rates than non-EU/EEC European countries. These findings are consistent with the analytical scenarios where RTAs promote upgrading in productivity levels. Also, the results reveal that Portugal has lower productivity growth rates compared to non-EU /EEC European countries. This finding is consistent with the analytical scenarios where RTAs lessen the incentives to implement productivity upgrading policies. Overall, the results reveal international differences in the implications of the EU/EEC membership for productivity in the agricultural sector.

This paper provide analysts and policy-makers with an interactive analytical background accompanied with an empirical evidence on the relationship between RTAs and agricultural technology and productivity. This is essential when designing international trade, innovation, and productivity policies for the agricultural sector. Finally, this paper lends itself to a follow-up empirical study that estimates the feedback effects from the RTA-induced changes in agricultural technology and productivity to the trade creation and trade diversion effects of RTAs.

\section{Endnote}

${ }^{a}$ Many empirical studies (e.g., Sarker and Jayasinghe, 2007; Grant and Lambert, 2008; Lambert and McKoy, 2009; Sun and Reed, 2010; Ghazalian et al., 2011) reported increasing effects of several RTAs on international trade in agricultural products between member countries (i.e., trade creation effects), which often significantly exceed the decreasing effects of these RTAs on international trade in agricultural products between member countries and non-member countries (i.e., trade diversion effects).

${ }^{\mathrm{b}}$ Funk (2003) found that increases in import competition levels have reduced Research and Development (R\&D) activities of manufacturing firms in the United States. Meanwhile, increases in foreign sales, brought about by real exchange rate depreciation, have enhanced their R\&D activities. Salomon and Shaver (2005) reported positive feedback effects from exporting activities to innovation activities. Bloom et al. (2011) found that European manufacturing firms have upgraded their productivity levels, and their 
innovation and R\&D activities in response to increases in imports from China. Ghazalian (2012) found that private R\&D expenditures of the food processing sectors in the Organization for Economic Cooperation and Development (OECD) countries have responded positively to increases in exports but have reacted negatively to increases in import competition levels in domestic markets.

${ }^{\mathrm{c} B a l d w i n}$ and $\mathrm{Gu}$ (2004) indentified several channels through which the growth of productivity levels occurred. These channels are: 1) exposure to higher levels of international competition in foreign markets, 2) learning-by-exporting where knowledge spillover and experience derived from exporting activities promote increases in industrial productivity levels, and 3) economies of scale realized through higher levels of product specialization.

${ }^{d}$ The supply schedules of country F and country J to country $\mathrm{H}$ encompass various international trade costs, particularly transportation, insurance, and information costs. For instance, consider the case where country $\mathrm{H}$ is geographically closer to country $\mathrm{F}$ than to country J. Thus, country F's exports require lower transportation and insurance costs than country J's exports. In this case, the wedge between $S_{F}$ and $S_{\text {J would reflect }}$ larger production efficiency differences.

${ }^{\mathrm{e}}$ The likelihood that the welfare gains from the RTA formation (i.e., [CKL + GMN]) is larger than the welfare losses (i.e., [LMVU]) is function of several factors. For example, this likelihood increases when the wedge between $S_{F}$ and $S_{J}$ is relatively small. It also increases with a more elastic demand schedule of country $\mathrm{H}$ and with a higher nondiscriminatory tariff rate imposed by country $\mathrm{H}$.

${ }^{\mathrm{f}}$ Alternatively, country H's total imports can decrease when the magnitude of the rightward shift from $S_{H}$ to $S_{H}(t)$ is significantly larger than the magnitude of the downward shift from $S_{\mathrm{F}}$ to $\mathrm{S}_{\mathrm{F}}(\mathrm{l})$.

${ }^{\mathrm{g}}$ Alternatively, when assuming that the hypothetical annulment of the RTA would induce a shift in country H's supply schedule back to its pre-RTA formation position (i.e., $\mathrm{S}_{\mathrm{H}}$ ), the implicit losses in governmental tariff revenues can be set at [CGVU].

${ }^{\mathrm{h}}$ Domestic and foreign agricultural producers could be also compelled to upgrade their marketing strategies and to introduce new product attributes. Such adjustments would be graphically expressed through a rightward shift in the demand curve of country $\mathrm{H}$ (i.e., $\mathrm{D}_{\mathrm{H}}$ ), implying larger positive welfare effects.

iAlternatively, consider the case where the annulment of the RTA, which lessens the import competition level in the domestic market, induces a shift in country H's supply schedule back to its pre-RTA formation position (i.e., back to $S_{H}$ ). Then, the losses in governmental tariff revenues can be set at [CGVU].

${ }^{j}$ As discussed in endnote $h$, a rightward shift in the demand curve of country $\mathrm{H}$ (i.e., $\mathrm{D}_{\mathrm{H}}$ ) can also occur, leading to supplementary positive welfare effects.

${ }^{k}$ These countries are: Austria, Denmark, Finland, France, Germany, Iceland, Italy, the Netherlands, Norway, Portugal, Spain, Sweden, Switzerland, and the United Kingdom.

${ }^{1}$ The OMCs in our dataset are: France, Germany, Italy, and the Netherlands.

${ }^{\mathrm{m}}$ The continuing members of the EFTA in our dataset are: Iceland, Norway, and Switzerland. Austria, Finland, and Sweden ceased to be EFTA members when they become members of the EU in 1995. 


\section{References}

Aghion P, Howitt P (1998) Endogenous Growth Theory. Massachusetts Institute of Technology (MIT) Press, Cambridge, MA Anania G, McCalla AF (1995) Assessing the Impact of Agricultural Technology Improvements in Developing Countries in the Presence of Policy Distortions. European Review of Agricultural Economics 22(1):5-24

Baldwin JR, Gu W (2004) Trade Liberalization: Export-market Participation, Productivity Growth and Innovation. Oxford Review of Economic Policy 20(3):372-392

Baumol WJ (1986) Productivity Growth, Convergence, and Welfare: What the Long-Run Data Show. Am Econ Rev 76(5):1072-1085

Bloom N, Draca M, van Reenen J (2011) “Trade Induced Technical Change: The Impact of Chinese Imports on Innovation, IT, and Productivity". In: Working Paper No. 16717. National Bureau of Economic Research (NBER), Cambridge, MA

Bustos P (2011) Trade Liberalization, Exports, and Technology Upgrading: Evidence on the Impact of MERCOSUR on Argentinian Firms. Am Econ Rev 101(1):304-340

Caselli F, Esquivel G, Lefort F (1996) Reopening the Convergence Debate: A New Look at Cross-Country Growth Empirics. Journal of Economic Growth 1(3):363-389

Caves RE (1985) International Trade and Industrial Organization: Problems, Solved and Unsolved. European Economic Review 28(3):377-395

Costantini J, Melitz MJ (2008) The Dynamics of Firm-Level Adjustment to Trade Liberalization. In: Helpman E, Marin D, Verdier T (eds) The Organization of Firms in a Global Economy. Cambridge, MA, Harvard University Press

Ederington J, McCalman P (2008) Endogenous Firm Heterogeneity and the Dynamics of Trade Liberalization. Journal of International Economics 74(2):422-440

Frankel JA (1997) Regional Trading Blocs in the World Economic System. Institute for International Economics, Washington, DC

Funk M (2003) The Effects of Trade on Research and Development. Open Economies Review 14(1):29-42

Ghazalian PL (2012) Assessing the Effects of International Trade on Private R\&D Expenditures in the Food Processing Sector. Industry and Innovation 19(4):349-369

Ghazalian PL, Larue B, Gervais J-P (2011) Assessing the Implications of Regional Preferential Market Access for Meat Commodities. Agribusiness: An International Journal 27(3):292-310

Grant JH, Lambert DM (2008) Do Regional Trade Agreements Increase Members' Agricultural Trade? American Journal of Agricultural Economics 90(3):765-782

Grossman GM, Helpman E (1991) Innovation and Growth in the Global Economy. MIT Press, Cambridge, MA

Josling T (2011) Agriculture. In: Chauffour J-P, Maur J-C (eds) Preferential Trade Agreement Policies for Development: A Handbook. Washington, DC, The World Bank

Krugman P (1991) Is Bilateralism Bad? In: Helpman E, Razin A (eds) International Trade and Trade Policy. Cambridge, MA, MIT Press

Lambert D, McKoy S (2009) Trade Creation and Diversion Effects of Preferential Trade Associations on Agricultural and Food Trade. Journal of Agricultural Economics 60(1):17-39

Levinsohn J (1991) "Testing the Imports-as-Market-Discipline Hypothesis". Working Paper No. 3657. National Bureau of Economic Research (NBER), Cambridge, MA

Lileeva A, Trefler D (2010) Improved Access to Foreign Markets Raises Plant-Level Productivity... for Some Plants. The Quarterly Journal of Economics 125(3):1051-1099

Pavcnik N (2002) Trade Liberalization, Exit, and Productivity Improvements: Evidence from Chilean Plants. Rev Econ Stud 69(1):246-276

Perdikis N (2007) Trade Agreements: Depth of Integration. In: Kerr WA, Gaisford JD (eds) Handbook on International Trade Policy. Cheltenham, UK, Edward Elgar Publishing

Pomfret R (1986) The Theory of Preferential Trading Arrangements. Review of World Economics 122(3):439-465

Pugel TA (1978) International Market Linkages and U.S. Manufacturing. Ballinger Publishing, Cambridge, MA

Salomon RM, Shaver JM (2005) Learning by Exporting: New Insights from Examining Firm Innovation. Journal of Economics and Management Strategy 14(2):431-460

Sarker R, Jayasinghe S (2007) Regional Trade Agreements and Trade in Agri-food Products: Evidence for the European Union from Gravity Modeling Using Disaggregated Data. Agricultural Economics 37(1):93-104

Sun L, Reed MR (2010) Impact of Free Trade Agreements on Agricultural Trade Creation and Trade Diversion. American Journal of Agricultural Economics 92(5):1351-1363

Viner J (1950) The Customs Union Issue. Carnegie Endowment, New York, NY

World Trade Organization (WTO) (2012) Regional Trade Agreements. Retrieved November., from http://www.wto.org/ english/tratop_e/region_e/region_e.htm

10.1186/2193-7532-1-7

Cite this article as: Ghazalian: On the relationship between regional trade agreements and agricultural

technology and productivity. Agricultural and Food Economics 2013, 1:7 